\title{
General adiposity and adipose tissue distribution in young women from Warsaw
}

\author{
Anna Kopiczko', Joanna Cieplińska² \\ ${ }^{1}$ Department of Anthropology and Health Promotion, Department of Biomedical Sciences \\ Józef Piłsudski University of Physical Education, Warsaw, Poland \\ 2 Higher School of Rehabilitation, Warsaw, Poland
}

\begin{abstract}
Aim. The aim of this study was to determine the overall adiposity and adipose tissue distribution in young women from Warsaw.

Material and methods. The study covered 550 women from Warsaw. The following research methods were applied: bioelectric impedance, measurement of body weight, body height, waist and hip circumference, body mass index (BMI), adipose tissue distribution Waist-to-Hip Ratio (WHR), Waist-to-Height Ratio (WHtR); waist circumference was also analyzed based on the criterion of the International Diabetes Federation (IDF).

Results. The average value of body mass index pointed to the correct values within $18.5-24.9 \mathrm{~kg} / \mathrm{m}^{2}$ range, while the BMI distribution in the studied group covered a wide range, starting from values characteristic for the state of emaciation up to values indicating III $^{\circ}$ obesity. Analysis of adipose tissue distribution based on WHR indicator showed existence of central adiposity, or abdominal adiposity, in case of more than $60 \%$ of the surveyed women. However, based on WHtR indicator that takes into account waist circumference and body height, abdominal obesity was found in case of slightly more than $30 \%$ of women. Analysis of the waist circumference measurement showed that abdominal (visceral) adiposity was found in case of half of the surveyed women. Average overall adiposity was $18.5 \mathrm{~kg}$. Adiposity on the left and right sides of the individual body segments did not differ significantly.

Conclusion. Overweight and obesity connected to the risk of developing cardiovascular disease exist among young women from Warsaw. Among the surveyed women a significant percentage of people with abdominal (central) type of adiposity was found, which creates the increased risk of cardiovascular disease. Prevention of cardiovascular disease should be based not only on the assessment of the overall adipose tissue and BMI but also on the assessment of its distribution in the body. Young women from Warsaw should be covered by preventive actions in order to prevent the development of cardiovascular disease through health education programs.
\end{abstract}

Key words: distribution of adipose tissue, bioelectric impedance, women.

\section{Introduction}

Excessive adiposity is a well-documented risk factor for many diseases of civilization and in particular arterial hypertension, atherosclerosis, ischemic heart disease, hyperlipidemia and hypercholesterolemia, type 2 diabetes, as well as the majority of malignant neoplasms [1, 2].

Many epidemiological studies and experimental clinical trials demonstrated the existence of a strong causal link between obesity and cardiovascular disease $[3,4]$.
Adipose tissue is a storage of fat and serves as an organ of internal secretion, it is dispersed throughout the body, and its most important locations are abdominal visceral, subcutaneous abdominal and gluteal-femoral, which differ in structure, function, gene expression, metabolic and endocrine activity, and differently affect the functioning of liver and central nervous system (CNS) [5].

Abdominal obesity is the accumulation of adipose tissue in the abdomen, not proportional to the total 
amount of fat in the body, which is an important and independent risk factor for many metabolic complications [6].

Abdominal obesity rating in epidemiological studies is mainly done indirectly based on anthropometric measurements and indicators. One of the most commonly used indicators is WHR (Waist-to-Hip Ratio), which is calculated based on the ratio of the circumference of the waist to that of the hips, whereas a division covers android (abdominal) and gynoidal (gluteal-femoral) obesity. The division criteria are based on the links between the WHR and the occurrence of the increased risk of developing cardiovascular disease [7].

The distribution and amount of the adipose tissue varies in terms of gender. The amount and size of adipocytes in the subcutaneous tissue are higher in case of females in comparison to men, and, therefore, the percentage of fat in relation to the total body mass is higher in case of women [8].

\section{Aim}

The aim of the study was to determine the overall adiposity and adipose tissue distribution in young women from Warsaw.

\section{Material and methods}

The study covered 550 women from Warsaw aged 22.1 \pm 2.9 years (mean $\pm \mathrm{SD}$ ). The study was conducted in the period from January to April 2013 in the Laboratory of Clinical Trials of Higher School of Rehabilitation in Warsaw. The qualification for inclusion to the study was the women's written consent for voluntary participation in the project. All people joining the study were informed of the purposes and methods of research and the possibility of cancellation at any stage. Contraindications for measuring bioelectrical impedance (BIA): the early period of pregnancy, defibrillators and pacemakers, epilepsy, people with metal prostheses, prosthesis, implants were the criteria for exclusion from the srudy.

The research program, its goals, objectives and selected research methods obtained the certificate of conformity with the rules of ethics of the Senate Ethics Committee for Scientific Research at the Józef Piłsudzki University of Physical Education in Warsaw.

The following research methods were used:

- bioelectrical impedance analysis with the use of the TANITA BC 418 analyzer;

- anthropometric measurements of the following morphological characteristics: body weight $(\mathrm{kg})$, body height $(\mathrm{cm})$, waist circumference $(\mathrm{cm})$ and hip circumference $(\mathrm{cm})$;

- indicators: body mass index (BMI), adipose tissue distribution WHR (Waist-to-Hip Ratio), WHtR (Waist-to-Height Ratio); waist circumference was also analyzed based on the criterion of the International Diabetes Federation (IDF), where the abdominal obesity for women is when the waist circumference is: $\geqslant 80 \mathrm{~cm}$;

- statistical methods with the use of STATISTICA software.

\section{Results and discussion}

Table 1 presents the descriptive statistics of anthropometric measurements of the studied group. The average value of the body mass index indicated the correct values within the range of $18.5-24.9 \mathrm{~kg} / \mathrm{m}^{2}$, while the BMI distribution in the studied group was in a wide range, starting from the values characteristic for the state of emaciation up to the values indicating $\mathrm{III}^{\circ}$ obesity. The average value of the WHR indicator pertaining to adipose tissue distribution indicates the type of visceral adiposity, otherwise as central, abdominal or androidal. The ratio of waist circumference to body height presented as the WHtR indicator reached the value below the criteria of the International Diabetes Federation, what indicates the abdominal obesity (Table 1).

BMI distribution analysis in the studied group of women $(n=550)$ showed that the largest percentage of women was characterized by a normal weight, while there was noted both the cases of emaciation and weight deficiency in a total of $6.7 \%$ of the surveyed women. Overweight was observed in $12.7 \%$ of women, whereas obesity, including $\mathrm{II}^{0}$ obesity, in 6.6\% (Table 2).

The data obtained are consistent with research of the second year students of the full-time Masters studies at the Faculty of Physical Education and the students of the second year of Masters studies at the Faculty of Human Nutrition and Consumer Agricultural University aged 22-28. Body mass index of most women was in the range of normal values, i.e., $18.5-25[\mathrm{~kg} /$ $\mathrm{m}^{2}$ ] (95\% in the AWF, $87 \%$ in the WAU). Both groups noted values below normal (5\% in both cases), and excessive body weight $\left(\mathrm{BMI}>25\left[\mathrm{~kg} / \mathrm{m}^{2}\right]\right)$ in $7 \%$ of WAU students [9].

In the studies of Charkiewicz et al. anthropometric parameters of the tested female UM students in Bialystok showed that BMI in 75\% people was in the normal range, while $23 \%$ were underweight, and only $2 \%$ - overweight [10]. 
Research conducted on students from the Universities of Poznan demonstrated higher scores, respectively: $38 \%$ were underweight and $6.7 \%$ were overweight [11].

In most studies of young women in Poland there is stated a significant proportion of normal nutritional status, however, there are still noted the increasing cases of women who are overweight and obese at such a young age.

These results are important mainly due to the fact that the BMI, as an index of nutritional status, is highly correlated with the total body fat content $[12,13]$.

However, we must remember that using only the analysis of trends of BMI changes, we cannot unequivocally demonstrate the negative health consequences of obesity. As this indicator does not distinguish the body content of the adipose tissue from muscle tissue, there is also no information concerning its distribution.

Therefore, it is considered as better to assess the distribution of body fat based on the WHtR index, regarded as an effective indicator of the body fat, particularly in the abdominal type. Given the waist circumference and body height, abdominal obesity was found in slightly more than $30 \%$ of the women (Table 3). This result is all the more important beasue WHtR is a recognized indicator of the risk of cardiovascular disease and metabolic syndrome [12].

Whereas the WHR indicator showed the presence of central adiposity (abdominal type) in more than
$60 \%$ of the surveyed women. This may indicate that impaired fat distribution, consisting of the increased ratio of the visceral fat to the subcutaneous tissue. In humans, abdominal obesity is an independent risk factor of metabolic syndrome, type II diabetes, cardiovascular disease and certain types of cancer [13, 14, 15].

Whereas applying the analysis of the measurement only of the waist circumference according to the International Diabetes Federation criteria showd that abdominal fat type occurred in the half of the examined. In practice, due to the role of visceral fat in the development of complications of obesity, WC is increasingly gaining recognition, which is regarded, just like WHtR, as one of the most important indicators of body fat [16].

The amount of general and segmental adipose tissue based on the analysis of body composition with the use of bioelectrical impedance (BIA) method showed a large variation in the group of examined women from Warsaw. The average overall adiposity was 18.5 $\mathrm{kg}$, while the difference between the lowest and the greatest mass of adipose tissue was $48.3 \mathrm{~kg}$. In case of the percentage of total adipose tissue similar trends were stated. Adiposity on the left and right sides of the individual body segments did not differ significantly (Table 4).

In people with central obesity there is accumulated both the visceral adipose tissue and the subcutaneous abdominal tissue. Several studies have shown that both deposits, regardless of themselves, condition the

Table 1. Somatic characteristics of studied women (average \pm SD, minimum, maximum)

\begin{tabular}{lccc}
\hline & Average \pm SD & Minimum value & Maximum value \\
\hline Body weight $[\mathrm{kg}]$ & $63.2 \pm 11.5$ & 42.7 & 115 \\
\hline Body height $[\mathrm{cm}]$ & $166.9 \pm 5.3$ & 155 & 186 \\
\hline Waist circumference $[\mathrm{cm}]$ & $79.5 \pm 9.0$ & 58 & 116 \\
\hline Hips circumference $[\mathrm{cm}]$ & $92.9 \pm 6.6$ & 68 & 115 \\
\hline BMI $\left[\mathrm{kg} / \mathrm{m}^{2}\right]$ & $22.7 \pm 3.8$ & 16.7 & 42.2 \\
\hline WHR $^{*}$ & $0.86 \pm 0.07$ & 0.68 & 1.13 \\
\hline WHtR $^{* *}$ & $0.48 \pm 0.06$ & 0.35 & 0.71 \\
\hline
\end{tabular}

* waist-to-hip ratio, ** waist-to-height ratio

Table 2. The distribution of Body Mass Index (BMI) in the studied group of women

\begin{tabular}{lcc}
\hline \multicolumn{1}{c}{ Classification of nutritional status } & BMI $\left[\mathrm{kg} / \mathrm{m}^{2}\right]$ & \% of women $(\mathrm{n}=550)$ \\
\hline Emaciation & $16.0-16.9$ & $1 \%$ \\
\hline Underweight & $17.0-18.49$ & $5.7 \%$ \\
\hline Proper body weight & $18.5-24.9$ & $74 \%$ \\
\hline Overweight & $25.0-29.9$ & $12.7 \%$ \\
\hline Obesity ${ }^{\circ}$ & $30.0-34.9$ & $5.7 \%$ \\
\multicolumn{1}{|c}{} & $35.0-39.9$ & $0.3 \%$ \\
\multicolumn{1}{|c}{} & $>40.0$ & $0.6 \%$ \\
\hline Overall obesity & $\geqslant 30$ & $6.6 \%$ \\
\hline
\end{tabular}


Table 3. Distribution of adipose tissue in the studied group of women $(n=550)$ based on WHR and WHtR indicators and waist circumference

\begin{tabular}{lcc}
\hline \multicolumn{1}{c}{ Distribution of adipose tissue } & Value of indicator & \% of women ( $\mathrm{n}=550)$ \\
\hline & WHR (waist-to-hip ratio) \\
\hline Androidal adiposity (abdominal) & $\geqslant 0.85$ & $60.3 \%$ \\
\hline Gynoidal adiposity (gluteal-femoral) & $\leqslant 0.85$ & $39.7 \%$ \\
\hline \multicolumn{3}{c}{ WHtR (waist-to-height ratio) } \\
\hline Central adiposity (abdominal) & $\geqslant 0.5$ \\
\hline & Waist circumference & $30.3 \%$ \\
\hline Central adiposity (abdominal) & $\geqslant 80$ & $50 \%$ \\
\hline
\end{tabular}

Table 4. The amount of general and segmental adipose tissue based on the analysis of body composition with the use of bioelectrical impedance (BIA)

\begin{tabular}{llccc}
\hline & Average \pm SD & Minimum value & Maximum value \\
\hline Overall amount of adipose tissue $[\mathrm{kg}]$ & $18.5 \pm 8.0$ & 6.2 & 54.4 \\
\hline Percentage of adipose tissue [\%] & $27.7 \pm 7.2$ & 12.5 & 51.4 \\
\hline \multirow{3}{*}{$\begin{array}{l}\text { Segmental amount } \\
\text { of adipose tissue } \\
{[\mathrm{kg}]}\end{array}$} & Right lower limb & $3.7 \pm 1.3$ & 0.9 & 10.3 \\
\cline { 2 - 5 } & Left lower limb & $3.6 \pm 1.3$ & 1.1 & 10.1 \\
\cline { 2 - 5 } & Right upper limb & $0.9 \pm 0.5$ & 0.1 & 3.9 \\
\cline { 2 - 5 } & Left upper limb & $1.0 \pm 0.6$ & 0.2 & 4.3 \\
\cline { 2 - 5 } & Trunk & $8.9 \pm 4.8$ & 1.7 & 30.5 \\
\hline \multirow{3}{*}{$\begin{array}{l}\text { The percentage of } \\
\text { segmental adipose } \\
\text { tissue }\end{array}$} & Right lower limb & $30.8 \pm 5.9$ & 7.8 & 47.4 \\
\cline { 2 - 5 }$[\%]$ & Left leg lower limb & $31.0 \pm 5.8$ & 9.4 & 47.9 \\
\cline { 2 - 5 } & Right upper limb & $27.7 \pm 8.2$ & 6.3 & 56.1 \\
\cline { 2 - 5 } & Left upper limb & $28.6 \pm 8.0$ & 7.6 & 56.9 \\
\cline { 2 - 5 } & Trunk & $24.7 \pm 8.4$ & 3.0 & 52.0 \\
\hline
\end{tabular}

development of insulin resistance, and the particularly adverse significance is found in the visceral adipose tissue. Its excess favours the development of the metabolic syndrome and hypertension and coronary heart disease [17].

Depending on the applied indicator, the percentage of women with abdominal obesity in the group of 550 surveyed women ranged from $30 \%$ to as much as $60 \%$. WHR $>0.8$ indicates the accumulation of visceral adipose tissue in women. In own studies, more than half (60.3\%) people had abdominal (visceral) adiposity. In comparison to the study of female students from Szczecin, where 29\% exceeded the value of the indicator for abdominal obesity, the result of young women from Warsaw indicates the increased risk of disease strongly correlated with this type of adipose tissue distribution [18].

The WHtR indicator allows to determine the risk of diet-related disease that can be prevented or minimized by a proper lifestyle, especially thanks to the proper nutrition and physical activity. The average value of the WHtR indicator in the studied group of women did not indicate the risk of developing the above mentioned diseases, including cardiovascular disease, similarly to the results of female students of the University of Szczecin being in the same age [18].

Abdominal obesity, called visceral, central or android obesity is characteristic for the "apple" body type. According to the medical sources, from the health point of view, among all types of obesity, abdominal obesity is highly unfavourable because most often it leads to the metabolic disorders, lipid metabolism disorders, diabetes, hypertension, which create the metabolic syndrome. Such adipose tissue distribution in connection with hypertension or diabetes significantly increases the risk of complications of cardiovascular diseases, leads to heart attack and stroke. In case of individuals with general or gluteal-femoral adiposity, the metabolic profile is more advantageous than in the central obesity $[19,20,21]$.

High consumption of alcohol, improper diet (highfat diet, fast foods), stress, smoking and many other factors associated with unhygienic lifestyle may result in the development of the abdominal obesity [22, 23, 24].

On the other hand, the increased physical activity, as indicated by the guidelines of preventive health care, reduces the risk of its occurrence [25]. 
Due to the differences in fat content, depending on the application of particular indicators, the discussed measurement methods may not be used interchangeably. While it is important to undertake research towards the risk assessment of the scale-dependent diseases of central fat distribution and increased total body fat among young women in order to develop effective programs for prevention of obesity and related health complications.

\section{References}

1. Calle EE, Rodriguez C, Walker-Thurmond K, Thun MJ. Overweight, obesity, and mortality from cancer in a prospectively studied cohort of U.S. Adult N Engl J Med. 2003;348:1625-38.

2. Wilborn C, Beckham J, Campbell B, et al. Obesity: prevalence, theories, medical consequences, managementand research directions. J Int Soc Sports Nutr. 2005;2:4-31.

3. Pupek-Musialik D, Bogdański P. Nadciśnienie związane z otyłością - spojrzenie hipertensjologa. In: Pupek-Musialik D (ed.). Otyłość i zespół metaboliczny. Via Medica, Gdańsk 2007, 1.

4. Czyżewski Ł. Nadwaga i otyłość jako czynniki ryzyka wystąpienia nadciśnienia tętniczego. Probl Piel. 2008;16 $(1,2): 128-35$

5. Siemińska L. Tkanka tłuszczowa. Patofizjologia, rozmieszczenie, różnice płciowe oraz znaczenie w procesach zapalnych i nowotworowych. Pol J Endocrinol. 2007;58(4): 330-42.

6. Suliga E. Otyłość brzuszna - metody oceny, przyczyny występowania, implikacje zdrowotne. Stud Med. 2012; 27(3):65-71.

7. Björntorp P. The associations between obesity, adipose tissue distribution and disease. Acta Med Scand. 1988; 723(Suppl.):121-34.

8. Giorgino F, Laviola L, Eriksson JW. Regional differences of insulin action in adipose tissue: insights from in vivo and in vitro studies. Acta Physiol Scand. 2005;183:13-30.

9. Myszkowska-Ryciak J, Kraśniewska A, Harton A, Gajewska D. Porównanie wybranych zachowań żywieniowych studentek Akademii Wychowania Fizycznego i Szkoły Głównej Gospodarstwa Wiejskiego w Warszawie. Probl Hig Epidemiol. 2011;92:931-4.

10. Charkiewicz WJ, Markiewicz R, Borowska MH. Ocena sposobu żywienia studentek dietetyki Uniwersytetu Medycznego w Białymstoku. Brom Chem Toksykol. 2009;42(3): 699-703.

11. Maruszewska M, Przysławski J, Bolesławska I. Składniki podstawowe w całodziennych racjach pokarmowych studentów uczelni poznańskich. Żyw Człow Metab. 2003; 30(1):347-501.
12. Przybylska D, Kurowska M, Przybylski P. Otyłość i nadwaga w populacji rozwojowej. Hygeia Public Health. 2012; 47:28-35.

13. Suliga E. Otyłość brzuszna - metody oceny, przyczyny występowania, implikacje zdrowotne. Studia Med. 2012; 27:65-71.

14. Fox CS, Massaro JM, Hoffman $U$, et al. Abdominal visceral and subcutaneous adipose tissue compartments: association with metabolic risk factors in the Framingham Heart Study. Circulation. 2007;116:39-48.

15. Mathieu P, Poirier P, Piborat $P$, et al. Visceral obesity: the link among inflammation, hypertension and cardiovascular disease. Hypertension. 2009;53:577-84.

16. Galic S, Oakhill JS, Steinberg GR. Adipose tissue as an endocrine organ. Mol Cell Endocrinol. 2010;316:129-39.

17. Chrostowska M, Szczęch R, Narkiewicz K. Nadciśnienie tętnicze związane z otyłością. Kardiologia na co dzień. 2007;3:106-11.

18. Rębacz-Maron E, Pawlak M, Michnik K. Stan odżywienia i aktywność fizyczna wśród studentek Uniwersytetu Szczecińskiego. Probl Hig Epidemiol. 2013;94:371-7.

19. Gabriely I, Barzilai N. Surgical removal of visceral adipose tissue: effects on insulin action. Curr Diab Rep. 2003; 3:201-6.

20. Empana JP, Ducimetiere P, Charles MA, et al. Sagittal abdominal diameter and risk of sudden death in asymptomatic middle-aged men: the Paris Prospective Study I. Circulation. 2004;110:2781-5.

21. Muzumdar R, Allison DB, Huffman DM, et al. Visceral adipose tissue modulates mammalian longevity. Aging Cell. 2008;7:438-40.

22. Schröder H, Morales-Molina JA, Bermejo S, et al. Relationship of abdominal obesity with alcohol consumption at population scale. Eur J Nutr. 2007;46:369-76.

23. Saarni SE, Pietiläinen K, Kantonen S, et al. Association of smoking in adolescence with abdominal obesity in adulthood: a follow-up study of 5 birth cohorts of Finnish twins. Am J Public Health. 2009;99:348-54.

24. Bergmann MM, Schütze M, Steffen $A$, et al. The association of lifetime alcohol use with measures of abdominal and general adiposity in a large-scale European cohort. Eur J Clin Nutr. 2011;65:1079-87.

25. Hairston KG, Vitolins MZ, Norris JM, et al. Lifestyle factors and 5-year abdominal fat accumulation in a minority cohort: the IRAS Family Study. Obesity (Silver Spring). 2012;20:421-7.

Correspondence address: Józef Piłsudski University of Physical Education 34 Marymoncka Street 00-968 Warszawa, Poland email: anka_kopiczko@interia.pl 